\title{
Hospitalization for community-acquired pneumonia in Alberta First Nations Aboriginals compared with non-First Nations Albertans
}

\author{
Thomas J Marrie $\mathrm{MD}^{1}$, Keumhee C Carriere $\mathrm{PhD}^{2}$, Yan Jin $\mathrm{MA}^{3}$, David H Johnson $\mathrm{MD}^{4}$
}

TJ Marrie, KC Carriere, Y Jin, DH Johnson. Hospitalization for community-acquired pneumonia in Alberta First Nations Aboriginals compared with non-First Nations Albertans. Can Respir J 2004;11(5):336-342.

BACKGROUND: The rates and outcomes of hospital admission for community-acquired pneumonia between First Nations Aboriginal and non-First Nations groups were compared.

METHODS: Alberta administrative hospital abstracts from April 1, 1997, to March 31, 1999, were analyzed, and each case of a First Nations Aboriginal person with pneumonia was matched by age and sex with three non-First Nations persons with pneumonia.

RESULTS: The First Nations Aboriginal age and sex-adjusted hospital discharge rate was 22 per 1000 (95\% CI 20.7 to 23.6) compared with 4.4 per 1000 (95\% CI 4.4 to 4.5 ) for the general population of Alberta. After accounting for comorbidity and severity of pneumonia, in-hospital mortality and hospital length of stay were lower for First Nations Aboriginals compared with the matched non-First Nations group (odds ratio $0.49 ; 95 \%$ CI 0.37 to 0.66 , and odds ratio $0.87 ; 95 \%$ CI 0.79 to 0.97 , respectively). The odds for 30 -day hospital readmission were higher in First Nations Aboriginals compared with the non-First Nations group (odds ratio 1.42 ; $95 \%$ CI 1.21 to 1.68). The cost per hospital admission for First Nations Aboriginals was $94 \%$ of the average cost for the matched non-First Nations group $(\mathrm{CDN} \$ 4,206)$. However, their median daily cost was 1.25 times higher (95\% CI 1.14 to 1.36 ) than the matched non-First Nations group.

CONCLUSIONS: First Nations Aboriginals had higher rates of hospitalization, rehospitalization and hospital costs for communityacquired pneumonia than non-First Nations Albertans. It was unlikely that the high rate of hospitalizations in First Nations Aboriginals was due to more severe pneumonia or greater comorbidity. Other unexplained factors increase the burden of this disease in First Nation Aboriginals.

Key Words: Aboriginal; Community-acquired pneumonia; Health service utilization
Hospitalisation pour pneumonie extrahospitalière en Alberta : comparaison entre les Autochtones des Premières nations et d'autres groupes de population

BUT : Comparer les taux d'hospitalisation pour des pneumonies extrahospitalières et les résultats entre les Autochtones des Premières nations et d'autres groupes de population.

MÉTHODE : Nous avons passé en revue les résumés de dossier d'hospitalisation datés entre le 1 er avril 1997 et le 31 mars 1999, et chaque cas de pneumonie chez un Autochtone des Premières nations a été apparié, selon l'âge et le sexe, à trois cas de pneumonie chez des personnes d'autres groupes.

RÉSULTATS : Le taux de congé rajusté selon l'âge et le sexe chez les Autochtone des Premières nations s'établissait à 22 pour 1000 (IC à $95 \%$ : 20,7-23,6) contre 4,4 pour 1000 (IC à $95 \%: 4,4-4,5$ ) pour la population en général en Alberta. Compte tenu de la comorbidité et de la gravité de la pneumonie, la mortalité intrahospitalière et la durée de séjour étaient plus faibles dans le groupe des Premières nations que dans l'autre groupe apparié (risque relatif indirect [RRI] : 0,49; IC à $95 \%$ : 0,37-0,66 et RRI : 0,87; IC à $95 \%: 0,79-0,97$ respectivement). Le risque de réadmission au bout de 30 jours était plus élevé chez les Autochtones que chez les personnes de l'autre groupe (RRI : 1,42; IC à $95 \%$ : 1,21-1,68). Enfin, le coût du séjour hospitalier chez les Autochtones s'élevait à $94 \%$ du coût moyen établi chez les malades appariés (4206 \$CAN); par contre, le coût quotidien médian était 1,25 fois (IC à $95 \%: 1,14-1,36$ ) supérieur à celui enregistré dans le groupe de population n'appartenant pas aux Premières nations.

CONCLUSIONS : Les Autochtones des Premières nations en Alberta ont connu des taux d'hospitalisation et de réadmission ainsi que des coûts d'hospitalisation plus élevés pour les pneumonies extrahospitalières que les autres Albertains. Il est peu probable que le taux élevé d'hospitalisation chez les Autochtones des Premières nations soit attribuable à des pneumonies plus graves ou a une comorbidité plus importante. Laugmentation du fardeau de la maladie chez les Autochtones des Premières nations s'expliquerait plutôt par d'autres facteurs.

${ }^{1}$ Department of Medicine and ${ }^{2}$ Department of Mathematical and Statistical Sciences, University of Alberta, Edmonton; ${ }^{3}$ Research and Evidence, Alberta Health and Wellness, Edmonton; ${ }^{4}$ Department of Public Health Sciences, University of Alberta, Edmonton, Alberta

Correspondence: Dr David Johnson, \#300 10219124 Street (Plaza 124), Edmonton, Alberta T5N 4A3. Telephone 780-413-5663, fax 780-413-7950, e-mail davidjohnson@cha.ab.ca

Reprints: Dr TJ Marrie, Department of Medicine, 2F1.12 Walter Mackenzie Health Sciences Centre, 8440-112 Street, Edmonton, Alberta

T6G 2B7. Telephone 780-407-6261,fax 780-407-3340, e-mail tom.marrie@ualberta.ca 
$\mathrm{R}^{\mathrm{c}}$ espiratory illness is the fourth leading cause of death among Canadian Aboriginals (1). Pneumonia is one of the most common reasons for hospitalization in the North American Aboriginal community, accounting for $4 \%$ of total hospital admissions (2). The reasons for the high rate of pneumonia hospitalization in Aboriginals are speculative. Predisposition to specific organisms may be indicated by the high rate of pneumococcal pneumonia and a high case fatality rate in some groups of Aboriginals (3). Other factors may be low immunization rates $(4,5)$, high prevalence of alcoholism leading to aspiration (4) or lack of access to timely care (6). The rate of hospitalization for pneumonia in Aboriginals may also be related to their lower socioeconomic status $(6,7)$. Low socioeconomic status may result in greater severity of illness and the need for hospitalization (8). Other explanatory factors may be difficulties due to long travel distances resulting in a lower threshold for admission $(9,10)$.

The designation of racial origin in Canadian administrative data is limited. Aboriginals identified by Indian and Northern Affairs Canada are referred to as status or First Nations Aboriginals and were identified in the administrative data. In the present study, the course of hospitalization for communityacquired pneumonia for First Nations Aboriginals and an agesex-matched group of non-First Nations Albertans were compared. It was hypothesized that the frequency and outcomes of hospitalizations for community-acquired pneumonia in the First Nations Aboriginal group differed from those of the matched non-First Nations group.

\section{METHODS}

Two administrative health service databases were used and the analysis was done within the protected environment of Alberta Health and Wellness, which is governed by provincial legislative guidelines on the confidentiality of health information. These data capture nearly the entire population and included a unique anonymous personal identifier, allowing linkage between data bases. The databases were the Canadian Institute for Health Information's Inpatient Discharge Abstract Database of hospital abstracts for the province of Alberta for 1997/1998 to 1998/1999, and the Alberta Health Insurance Plan Registry File for 1997 to 2000.

Community-acquired pneumonia was defined as the most responsible diagnosis, or any of the other 15 diagnosis codes defined to be Type 1 (pre-admit comorbidity) by the International Classification of Diseases, 9th revision, Clinical Modification (ICD-9-CM) (11) (values of 480.x to 487.x [pneumonia] or 507.x [aspiration pneumonia], excluding 484.x [pneumonia of infectious diseases classified elsewhere] $[12,13])$ found in the hospital abstracts.

\section{Exclusion criteria}

Exclusion criteria were:

- not an Alberta resident or not treated in an Alberta acute care facility;

- adjacent diagnosis related group defining hospitalization for a surgical procedure; and

- any previous hospitalization within 10 days of incident pneumonia case.

\section{Identifying First Nations Aboriginal status}

First Nations status (recorded as federal band registry identification with Indian and Northern Affairs Canada) were recorded in the Alberta Health Insurance Registry database, which was then linked to hospital abstracts. The comparison group for the population was created by matching each First Nations hospitalization by age, sex and year of hospitalization to non-First Nations pneumonia cases. Three controls for each First Nations Aboriginal case were used.

\section{Length of stay}

Length of stay was calculated as days between discharge and admission date. Transfers were attributed to the index admission and cumulative hospital length of stay calculated over all admissions. Alternate level of care referred to patients who remained in hospital but no longer required acute care. Alternate (not acute care) level of care days were subtracted from the length of stay. All active hospital acute care beds in each year per resident region were surveyed and maintained in the provincial databases.

\section{Comorbidity}

Comorbidity was defined as:

- age (age at the fiscal year end was used);

- sex;

- Charlson's comorbidity index (14) calculated using established definitions $(15,16)$; and

- alcohol-related problems (ICD-9-CM 291.x, 303.x, 305.x, V11.3) - extracted from any of the 16 hospital abstract diagnosis fields derived solely from the hospital chart.

\section{Severity}

Severity of pneumonia illness was defined as any of the following:

- transfer to hospital from a nursing home, long-term care institution or continuing care institution;

- transfer from another acute care facility as defined by readmission to hospital for the diagnosis of pneumonia within $48 \mathrm{~h}$ of previous discharge;

- special care unit admission (defined by each hospital);

- diagnosis code of respiratory failure or arrest (ICD-9-CM 518.81, 799.1);

- diagnosis code of hypotension or shock (ICD-9-CM 458.xx, $758.5 x)$

- procedure code for ventilation for greater than $96 \mathrm{~h}$ (ICD-9-CM 96.72); or

- procedure code for dialysis (ICD-9-CM 39.95 54.98).

\section{Defining hospital type by patient volume}

Hospitals admitting patients with community-acquired pneumonia were categorized into five groups on the basis of the average number of hospital discharges per year over the five-year study period, geographic location and medical school proximity. 
- Rural hospital were categorized by the number of pneumonia cases (50 and 108 representing the 50th and 75th percentiles, respectively).

- Rural hospitals with less than 50 cases/year (77 hospitals).

- Rural hospitals with 50 to 108 cases/year (27 hospitals).

- Regional hospitals (five hospitals) were categorized for each of the five nonmetropolitan regional health care cities (67 to 251 cases/year) and one high volume rural hospital (221 cases/year) was also added to this group.

- Metropolitan hospitals (seven hospitals) were located in the metropolitan health regions of Calgary and Edmonton hospitals (92 to 813 cases/year).

- Medical school metropolitan hospitals (2 hospitals) were located adjacent to medical schools - one hospital in each of two metropolitan centres (493 and 610 cases/year).

\section{Travelling distances}

Each case was mapped to the centre of a postal code and distances, as the 'crow flies,' between the centroids were calculated. The nearest hospital and actual admitting hospital distances to resident postal code were obtained for all nonurban residents (not residing in Calgary or Edmonton health regions). Urban resident distances were zero.

\section{Hospital costs}

Inpatient cost per resource group number was calculated using the provincially approved methodology $(17,18)$. Total costs combine the direct and indirect costs associated with an inpatient hospitalization from the time a patient was admitted to the hospital to the time of discharge. All costs were estimated for 1998/1999 and assumed similar for all the study years. The quality of the data reporting of costs in Alberta has been highly ranked by the Canadian Institutes for Health Information (19), which avoids methodological issues such as those that arise around the collection of cost data in the United States (20), in part, due to the use of prices rather than costs.

\section{Outcomes}

Outcomes were defined as:

- hospital discharge rate for the First Nations Aboriginal and matched non-First Nations group;

- length of hospital stay per hospital discharge;

- any rehospitalization between zero to 30 days after index pneumonia hospital discharge date, excluding rehospitalization for pneumonia between zero to two days after discharge (considered to be a hospital transfer); and

- median daily hospital cost per hospital discharge.

\section{Statistical analysis}

Age-sex-adjusted provincial hospital discharge rates and their 95\% CIs were calculated. The indirect standardization method using the two-year average, age-sex specific rates as the standard rates (18 to 34 years old, 10 year increment afterwards, up to 74 years old, 75 and over for each sex) was used. To calculate standard error for the standardized rates, the patient's age at a fixed date was necessary because a patient may have had more than one hospital discharge in a year. Age at the fiscal year end was used for the rates. Hospital discharge rates were compared using the Student's $t$ test (21). If the Student's $t$ test was significant, individual rate differences were compared using the overall 95\% CI after adjusting for multiple comparisons $(22,23)$.

To analyze the case-control data, the conditional logistic analysis tool LogXact V. 2.0 (1996) (Cytel Software Corporation, USA) was used. The data on continuous outcomes (costs and length of stay) were dichotomized using their median. Covariates were age, sex, year of hospitalization, per capita number of acute care beds per resident region in each study year, hospital type as defined above, exported case (ie, service region not equal to recipient region), urban or nonurban resident region, urban or nonurban service region, nursing home transfer to hospital, transfer to another hospital, special/intensive care unit admission, diagnosis code of respiratory failure/arrest, diagnosis code of hypotension/shock, procedure code for ventilation greater than $96 \mathrm{~h}$, procedure code for dialysis and number of comorbid diagnoses (zero, one, two, greater than two). Significance was $\mathrm{P}<0.05$.

\section{RESULTS}

During the two years of the study there were 1230 First Nations Aboriginal hospitalizations for 976 unique patients and 3691 non-First Nations hospitalizations for 3581 unique patients. Compared with the non-First Nations group, First Nations Aboriginals (Table 1) admitted to hospital with community-acquired pneumonia were more likely to reside in a rural region and were more likely to be hospitalized in a small rural hospital. The frequency of comorbidity in the two groups was similar but the case mix was different (ie, more diabetes and less malignancy in the First Nations Aboriginals). First Nations Aboriginals had less severe pneumonia (measured by frequency of admission to special/intensive care unit, hypotension/shock, respiratory failure/arrest and ventilation for greater than 96 h). A larger proportion of First Nations Aboriginals resided in a rural region and, on average, rural First Nations Aboriginals travelled a greater distance to a hospital compared with other rural residents (Table 2). More rural First Nations Aboriginals had services provided in a health region different from their region of residence and more were transferred to another acute care hospital after the initial hospital admission.

The First Nations Aboriginal hospital discharge rate for community-acquired pneumonia was five times greater than the Alberta provincial average (Table 3). The number of First Nations Aboriginals with alcohol-related problems was twice that of the non-First Nations group (Table 1). The First Nations Aboriginals hospital discharge rate for aspiration pneumonia was also five times greater than that of the Alberta population (Table 3), but the proportion of aspiration pneumonia to all pneumonia was similar in both groups. Length of hospital stay for First Nations Aboriginals was nearly two days shorter than that for the non-First Nations group. The rate of all cause readmissions for First Nations Aboriginals was approximately $25 \%$ greater that of the non-First Nations group (Table 4). The average hospital cost per day was greater for First Nations Aboriginals (Table 4). Cumulatively, one hospital accounted for $11.5 \%$, two hospitals accounted for $20 \%$ and 10 hospitals accounted for $52 \%$ of discharges. 
TABLE 1

Description of all hospital discharges for communityacquired pneumonia in First Nations Aboriginals and an age-sex-matched non-First Nations group

\begin{tabular}{|c|c|c|}
\hline & $\begin{array}{l}\text { First Nations } \\
\text { Aboriginal hospital } \\
\text { discharges } \\
(n=1230)\end{array}$ & $\begin{array}{c}\text { Age-sex-matched } \\
\text { non-First Nations } \\
\text { hospital discharges } \\
(n=3690)\end{array}$ \\
\hline Mean age in years (SD) & $53.5(19.5)$ & $53.7(19.4)$ \\
\hline Women (n [\%]) & $689(56.0)$ & $2067(56.0)$ \\
\hline $\begin{array}{l}\text { Transfer to hospital from a nursing home, } \\
\text { long-term care or continuing care ( } \mathrm{n}[\%] \text { ) }\end{array}$ & $4(0.3)$ & $89(2.4)$ \\
\hline Transfer to another acute hospital (n [\%]) & $36(2.9)$ & $78(2.1)$ \\
\hline Urban resident region (n [\%]) & $218(17.7)$ & $1672(45.3)$ \\
\hline Urban service region (n [\%]) & $299(24.3)$ & $1678(45.5)$ \\
\hline $\begin{array}{l}\text { Admitted to a hospital not located in } \\
\text { home region ( } \mathrm{n}[\%])\end{array}$ & $352(28.6)$ & $404(10.9)$ \\
\hline $\begin{array}{l}\text { Patient designated as no longer acute } \\
\text { care (alternate level of care) (n [\%]) }\end{array}$ & $7(0.6)$ & $34(0.9)$ \\
\hline \multicolumn{3}{|l|}{ Hospitals (n [\%]) } \\
\hline Less than 50 cases per year & $321(26.1)$ & $741(20.1)$ \\
\hline 50 to 108 cases per year & $387(31.5)$ & $767(20.8)$ \\
\hline Regional hospitals & $223(18.1)$ & $504(13.7)$ \\
\hline Metropolitan & $191(15.5)$ & $1152(31.2)$ \\
\hline $\begin{array}{l}\text { Metropolitan in proximity to a medical } \\
\text { school }\end{array}$ & $108(8.8)$ & $526(14.3)$ \\
\hline \multicolumn{3}{|l|}{ Comorbidity (n [\%]) } \\
\hline None & $607(49.3)$ & $1795(48.6)$ \\
\hline One & $408(33.2)$ & $1193(32.3)$ \\
\hline Two & $154(12.5)$ & $484(13.1)$ \\
\hline More than two & $61(5.0)$ & $218(5.9)$ \\
\hline Chronic obstructive pulmonary disease & $310(25.2)$ & $1040(28.2)$ \\
\hline Diabetes & $181(14.7)$ & $379(10.3)$ \\
\hline Malignancy & $35(2.8)$ & $254(6.9)$ \\
\hline Congestive heart failure & $137(11.1)$ & $374(10.1)$ \\
\hline $\begin{array}{l}\text { Vascular (acute myocardial infarction, } \\
\text { peripheral vascular disease, cerebral } \\
\text { vascular disease) }\end{array}$ & $73(5.9)$ & $311(8.4)$ \\
\hline $\begin{array}{l}\text { Alcohol problem recorded on hospital } \\
\text { abstract }\end{array}$ & $244(19.8)$ & $369(10.0)$ \\
\hline \multicolumn{3}{|l|}{ Severity of illness (n [\%]) } \\
\hline Special/intensive care unit admissions & $72(5.9)$ & $295(8.0)$ \\
\hline Hypotension/shock & $17(1.4)$ & $77(2.1)$ \\
\hline Respiratory arrest/failure & $32(2.6)$ & $166(4.5)$ \\
\hline Ventilation for more than $96 \mathrm{~h}$ & $9(0.7)$ & $59(1.6)$ \\
\hline In-hospital dialysis & $14(1.1)$ & $34(0.9)$ \\
\hline
\end{tabular}

TABLE 2

Description of community acquired pneumonia for nonurban residents only in First Nations Aboriginals and an age-sexmatched non-First Nations group

\begin{tabular}{lcc}
\hline & $\begin{array}{c}\text { First Nations } \\
\text { Aboriginals } \\
(\mathrm{n}=1012)\end{array}$ & $\begin{array}{c}\text { Age-sex matched } \\
\text { non-First Nations } \\
\text { Albertans } \\
(\mathrm{n}=\mathbf{2 0 1 8})\end{array}$ \\
\hline Mean distance to closest hospital $(\mathrm{km})$ & 21 & 6 \\
Mean distance to admitting hospital $(\mathrm{km})$ & 40 & 19 \\
Transfer to another acute hospital $(\mathrm{n}[\%])$ & $31(3.1)$ & $52(2.6)$ \\
Admitted to an out-of-region hospital $(\mathrm{n}[\%])$ & $314(31.0)$ & $275(13.6)$ \\
Hospitals (n [\%]) & $307(30.3)$ & $672(33.3)$ \\
Less than 50 cases per year & $372(36.8)$ & $735(36.4)$ \\
50 to 108 cases per year & $217(21.4)$ & $483(23.9)$ \\
Regional hospitals & $60(5.9)$ & $76(3.8)$ \\
Metropolitan & $56(5.5)$ & $52(2.6)$ \\
Metropolitan in proximity to a medical & & \\
$\quad$ school & & \\
\hline
\end{tabular}

TABLE 3

Age-sex-adjusted rates for community-acquired pneumonia in Alberta from April 1,1997, to March 31, 1999

\begin{tabular}{lcc}
\hline & \multicolumn{1}{c}{$\begin{array}{c}\text { First Nations } \\
\text { Aboriginals } \\
(\mathbf{n = 1 2 3 0 )}\end{array}$} & $\begin{array}{c}\text { All Alberta } \\
\text { patients } \\
(\mathbf{n}=\mathbf{1 6}, \mathbf{5 2 8})\end{array}$ \\
\hline $\begin{array}{l}\text { Age-sex-adjusted hospital discharge } \\
\text { rate for community-acquired pneumonia }\end{array}$ & $22.1(20.7-23.6)$ & $4.4(4.4-4.5)$ \\
$\begin{array}{l}\text { per } 1000 \text { population }(95 \% \mathrm{Cl}) \\
\text { Age-sex-adjusted hospital discharge } \\
\text { rate for aspiration pneumonia per 1000 } \\
\text { population }(95 \% \mathrm{Cl})\end{array}$ & $0.29(0.96-1.6)$ & \\
\hline
\end{tabular}

TABLE 4

Outcomes for community-acquired pneumonia in First Nations Aboriginals and an age-sex-matched non-First Nations group

\begin{tabular}{lcc}
\hline & $\begin{array}{c}\text { First Nations } \\
\text { Aboriginals } \\
(\mathrm{n}=1230)\end{array}$ & $\begin{array}{c}\text { Age-sex-matched } \\
\text { non-First Nations } \\
\text { Albertans } \\
(\mathrm{n}=3691)\end{array}$ \\
\hline $\begin{array}{l}\text { Length of stay in days (mean [SD]) } \\
\text { (median) }\end{array}$ & $6.1(8.5)$ & $7.8(13.7)$ \\
In-hospital mortality (n [\%]) & 4 & 5 \\
All cause 30-day readmissions* (n [\%]) & $260(21.8)$ & $508(14.8)$ \\
Readmission with a second pneumonia & $38(3.2)$ & $59(1.7)$ \\
$\quad$ within two to 10 days of discharge $(\mathrm{n}[\%])$ & & \\
Readmission with a second pneumonia \\
$\quad$ within 11 to 30 days of discharge* $(\mathrm{n}[\%])$ \\
$\begin{array}{l}\text { Average costs (1998/1999 CDN dollars) } \\
\text { per discharge }\end{array}$
\end{tabular}

*Note that denominator eliminates hospital death 
TABLE 5

Conditional logistic regression analysis for hospital death in First Nations Aboriginals and an age-sex-matched nonFirst Nations group

\begin{tabular}{lcc}
\hline & Odds ratio & $\mathbf{9 5 \% ~} \mathbf{~ I ~}$ \\
\hline First Nations Aboriginals & 0.49 & $0.37-0.66$ \\
Comorbidity & & \\
$\quad$ None & Reference & \\
One & 1.53 & $1.12-2.09$ \\
Two & 3.42 & $2.51-4.66$ \\
More than two & 4.78 & $3.16-7.23$ \\
Special care unit admission & 2.07 & $1.52-2.81$ \\
Transfer from nursing home & 2.67 & $1.72-4.14$ \\
Respiratory failure/arrest & 4.39 & $3.27-5.89$ \\
Hypotension/shock & 4.40 & $2.39-8.07$ \\
\hline
\end{tabular}

\section{TABLE 6}

Conditional logistic regression analysis for any rehospitalization between zero and 30 days after index pneumonia date in First Nations Aboriginals and an agesex-matched non-First Nations group

\begin{tabular}{lcc}
\hline & Odds ratio & $\mathbf{9 5 \%} \mathrm{Cl}$ \\
\hline First Nations Aboriginals & 1.42 & $1.21-1.68$ \\
Comorbidity & & \\
None & Reference & \\
One & 1.50 & $1.23-1.83$ \\
Two & 2.07 & $1.59-2.68$ \\
More than two & 2.05 & $1.45-2.89$ \\
Special care unit admission & 1.34 & $1.00-1.80$ \\
Respiratory failure/arrest & 1.74 & $1.06-2.87$ \\
Hospitals & & \\
Less than 50 cases per year & Reference & \\
50 to 108 cases per year & 1.02 & $0.80-1.30$ \\
Regional hospitals & 1.25 & $0.94-1.66$ \\
Metropolitan hospitals & 0.77 & $0.60-0.99$ \\
Metropolitan hospitals in proximity to & 0.98 & $0.74-1.30$ \\
$\quad$ a medical school & & \\
\hline
\end{tabular}

After accounting for comorbidity and severity of pneumonia (Tables 5-7), in-hospital mortality and hospital length of stay were lower for First Nations Aboriginals compared with the matched non-First Nations group (odds ratio 0.49; $95 \%$ CI 0.37 to 0.66 and odds ratio $0.87 ; 95 \%$ CI 0.79 to 0.97 , respectively), and the rate of 30-day hospital readmission was higher for First Nations Aboriginals compared with the non-First Nations group (odds ratio 1.42; 95\% CI 1.21 to 1.68). The cost per hospital admission for First Nations Aboriginals was $94 \%$ of the average cost of the matched non-First Nations group (CDN\$4,206). However, their daily average cost was 1.25 higher (95\% CI 1.14 to 1.36) than that of the matched non-First Nations (Table 8).

\section{DISCUSSION}

The hospital discharge rate for community-acquired pneumonia is approximately five times greater in First Nations
TABLE 7

Conditional logistic regression analysis for hospital length of stay* being longer than the median value of five days in First Nations Aboriginals and an age-sex-matched non-First Nations group

\begin{tabular}{lcc}
\hline & Odds ratio & $\mathbf{9 5 \%} \mathbf{C l}$ \\
\hline First Nations Aboriginals & 0.87 & $0.79-0.97$ \\
Comorbidity & & \\
None & Reference & \\
One & 1.20 & $1.08-1.34$ \\
Two & 1.41 & $1.21-1.63$ \\
More than two & 1.59 & $1.30-1.96$ \\
Transfer to another hospital & 2.55 & $1.97-3.31$ \\
Mechanical ventilation greater than $96 \mathrm{~h}$ & 2.18 & $1.68-2.83$
\end{tabular}

Hospitals

$\begin{array}{lcc}\text { Less than } 50 \text { cases per year } & \text { Reference } & \\ 50 \text { to } 108 \text { cases per year } & 1.11 & 0.96-1.29 \\ \text { Regional hospitals } & 1.54 & 1.31-1.82 \\ \text { Metropolitan hospitals } & 1.56 & 1.35-1.79 \\ \text { Metropolitan hospitals in proximity } & 1.66 & 1.39-1.97 \\ \quad \text { to a medical school } & & \end{array}$

${ }^{*}$ Length of stay $=1$, if length of stay is greater than five days (the median length of stay)

TABLE 8

Conditional logistic regression analysis for daily hospital cost $^{*}$ being higher than the median cost of $\$ 722.71$ in First Nations Aboriginals and an age-sex-matched non-First Nations group

\begin{tabular}{lcc}
\hline & Odds ratio & $\mathbf{9 5 \%} \mathbf{C l}$ \\
\hline First Nations Aboriginals & 1.25 & $1.14-1.36$ \\
Transfer from nursing home & 1.50 & $1.07-2.09$ \\
Transfer to another hospital & 0.53 & $0.38-0.74$ \\
Special care unit admission & 1.34 & $1.11-1.63$ \\
Respiratory failure/arrest & 1.49 & $1.17-1.89$ \\
Mechanical ventilation greater than $96 \mathrm{~h}$ & 0.52 & $0.34-0.77$ \\
\hline
\end{tabular}

${ }^{*}$ Cost $=1$, if the average cost per day per discharge is more than $\$ 722.71$ (the median cost)

Aboriginals compared with the Alberta population. It is unlikely that the high rate of hospitalizations in First Nations Aboriginals is due to more severe pneumonia because clinically, these hospitalizations were shorter in length and involved less specialized medical care (such as special/intensive care unit admission and mechanical ventilation greater than $96 \mathrm{~h}$ ). After adjustment (see regression methods), in-hospital mortality was lower among First Nations Aboriginals. As well, it is unlikely that the high rate of hospitalizations in First Nations Aboriginals was due to a generally unhealthy population because their comorbidty was similar to that of the matched non-First Nations group. Hospital costs during the first days of admission are greater due to investigations, greater severity of illness and the more intensive care required $(24,25)$.

The greatest morbidity and mortality burden for pneumonia falls disproportionately on the elderly $(26,27)$. First Nations 
Aboriginals hospitalized for community-acquired pneumonia were younger than the Albertan population hospitalized for community-acquired pneumonia (28). We used age- and sexmatched cases in the modelling to minimize differences in the two populations. The non-First Nations group was more likely to have an urban residence compared with First Nations Aboriginals. Rural First Nations Aboriginals were located at a farther distance from their local hospital compared with those in the rural non-First Nations group. Physicians may have been more likely to admit patients who did not reside in close proximity to the admitting hospital $(9,10)$. However, a greater distance to the local hospital did not account for the greater frequency of transfer to another acute care hospital (despite less comorbidity and severity of illness). As well, $31 \%$ of rural First Nations Aboriginals were admitted to a service region different from their resident region; over twice the frequency of the rural non-First Nations group. The distribution of hospitals used demonstrates that despite their more nonurban residency, rural First Nations Aboriginals were admitted to urban hospitals more frequently than those in the rural non-First Nations group. Thus, not only did the rate of hospitalization differ in the First Nations Aboriginal population, the location of the hospital with respect to residence was also different. First Nations Aboriginals have many other important differences from non- First Albertans. Alcohol/substance abuse, smoking (29-31), diabetes $(32,33)$ and end-stage chronic renal failure are more common in First Nations Aboriginals $(34,35)$. In the present study, we controlled for other comorbities. In addition, aspiration pneumonia (related to substance abuse) was not proportionally more prevalent and chronic obstructive pulmonary disease (as related to smoking) was not more frequent in First Nations Aboriginals.

There are a number of limitations to the present study. First Nations Aboriginals registered with Indian and Northern Affairs Canada may not be reflective of Aboriginals without registration. The Aboriginal population is not considered a homogenous group because they are composed of First Nations people registered with Indian and Northern Affairs Canada and include nonregistered Aboriginals, Metis and Inuit $(36,37)$. The place of residence for First Nations Aboriginals may be more related to band location rather than actual domicile. Systematic underreporting of out-of-hospital death in First Nations Aboriginals may result in an overestimation of those at risk and an underestimation of pneumonia rates. These limitations underscore why secondary use of administrative data should be interpreted with caution. Population-based administrative database research is highly generalizable but limited in clinical detail. We attempted to adjust for case severity (hypotension/shock, respiratory arrest/failure, ventilation, special care unit admission, export to another region, transfer to another hospital) and case mix (comorbidity, transfer from nursing home, age, sex) but may not have captured all variations (38). These variables are likely less reliable than a clinically derived pneumonia index (39). Individual data about the use of influenza and pneumococcal vaccines were unavailable. In particular, the influenza vaccine has been shown to reduce the hospitalization rate for pneumonia $(40,41)$ and its use was lower in Aboriginals $(4,5)$.

\section{CONCLUSIONS}

It is unlikely that the high rate of hospitalizations among First Nations Aboriginals is due to more severe pneumonia or having more comorbidity. Due to the higher rates of hospitalization and subsequent rehospitalization, total hospital costs for community-acquired pneumonia in First Nations Aboriginals was greater than the cost for the non-First Nations group. Understanding the underlying reasons for the increased frequency of hospitalizations in First Nations Aboriginals and the possible remedies require further study. For example, it is important to obtain a better understanding of the reasons physicians choose to admit or not admit patients with pneumonia at a defined degree of severity and to determine if these choices are systematically different in First Nations Aboriginals. Given the concentration of First Nations Aboriginal hospitalizations in a few hospitals, local efforts may be helpful. For example, a high rate of pneumococcal pneumonia in First Nations Aboriginals admitted to these hospitals may support a local public health program of universal pneumococcal vaccination (41). With a mean age of 53 years, most of the First Nations patients who require admission to hospital for the treatment of pneumonia would not qualify for pneumococcal vaccine under the program in Alberta, which recommends vaccination for all adults 65 years of age and older. Studying the incidence of pneumococcal pneumonia in First Nations Aboriginals could substantiate the potential benefit for a lowered age of pneumococcal vaccination.

\section{REFERENCES}

1. Fraser-Lee NJ, Hessel PA. Acute respiratory infections in the Canadian Native Indian population: A review. Can J Public Health 1994;85:197-200.

2. Rhoades ER. The major respiratory diseases of American Indians. Am Rev Respir Dis 1990;141:595-600.

3. Cortese MM, Wolff M, Almeido-Hill J, Reid R, Ketcham J, Santosham M. High incidence rates of invasive pneumococcal disease in the White Mountain Apache population. Arch Intern Med 1992;152:2277-82.

4. Buchwald D, Sheffield J, Furman R, Hartman S, Dudden M, Manson S. Influenza and pneumococcal vaccination among Native American elders in a primary care practice. Arch Intern Med 2000;160:1443-8.

5. Davidson M, Parkinson AJ, Bulkow LR, Fitzgerald MA, Peters HV, Parks DJ. The epidemiology of invasive pneumococcal disease in Alaska, 1986-1990 - ethnic differences and opportunities for prevention. J Infect Dis 1994;170:368-76.

6. Royal Commission on Aboriginal Peoples. Looking Forward, Looking Back - Report of the Royal Commission on Aboriginal Peoples, Volume 1. Ottawa: Supply and Services Canada, 1996.

7. Canadian Institute of Child Health. The health of Canada's children: A CICH profile, 3rd edn. Ottawa: Canadian Institute of Child Health, 2000.

8. Dixon AS. Survey of rural practice: Rainy River 1075 (Part 4 Comparison of morbidity in Indian and non-Indian patients) Can Fam Physician 1976;22;29-37.

9. Evers SE, Rand CG. Morbidity in Canadian Indian and non-Indian children in the second year. Can J Public Health 1983;74:191-4.

10. Robinson GC, Evans RG. A survey of pediatric hospital utilization by Indian children in British Columbia. Can J Public Health 1973;64:154-60.

11. Hart AC, Hopkins CA. International Classification of Diseases, 9th Revision, Clinical Modification, 6th edn. Salt Lake City: Ingenix, 2002.

12. Marrie TJ, Durant H, Sealy E. Pneumonia - the quality of medical records. Med Care 1987;25:20-4.

13. Draper D, Kahn KL, Reinisch EJ, et al. Studying the effects of the DRG-based prospective payment system on quality of care. Design, sampling, and fieldwork. JAMA 1990;264:1956-61. 
14. Charlson ME, Pompei P, Ales KL, MacKenzie CR. A new method of classifying prognostic comorbidity inlongitudinal studies: Development and validation. J Chronic Dis 1987;40:373-83.

15. Deyo RA, Cherkin DC, Ciol MA. Adapting a clinical comorbidity index for use with ICD-9-CM administrative databases. J Clin Epidemiol 1992;45:613-9.

16. Romano PS, Roos LL, Jollis JG. Adapting a clinical comorbidity index for use with ICD-9-CM administrative data: Differing perspectives. J Clin Epidemiol 1993;46:1075-9.

17. Regional Health Authority Global Funding Manual, 2000-01. Edmonton: Health Funding and Costing Branch, Alberta Health and Wellness, 2000.

18. Guidelines for Management Information Systems in Canadian Health Service Organizations. Ottawa: Canadian Institute for Health Information, 1999.

19. McKillop I, Pink GH, Johnson LM. The Financial Management of acute care in Canada: A review of funding, performance monitoring and reporting practices. Ottawa: Canadian Institute for Health Information, 2001:83.

20. Magnus SA, Smith DG. Better medicare cost report data are needed to help hospitals benchmark costs and performance. Health Care Manage Rev 2000;25:65-76.

21. Carriere KC, Roos LL. Comparing standardized rates of events. Am J Epidemiol 1994;140:472-82.

22. Seber GAF. Linear Regression Analysis. New York: Wiley, 1977.

23. Hosmer DW, Lemeshow S. Applied Logistic Regression. New York: Wiley, 1989.

24. Koivula I, Sten M, Makela PH. Prognosis after community-acquired pneumonia in the elderly: A population-based 12-year follow-up study. Arch Intern Med 1999;159:1550-5.

25. Fine MJ, Pratt HM, Obrosky DS, et al. Relation between length of hospital stay and costs of care for patients with community-acquired pneumonia. Am J Med 2000;109:378-85.

26. Marrie TJ, Haldane EV, Faulkner RS, Durant H, Kwan C. Community-acquired pneumonia requiring hospitilization: Is it different in the elderly? J Am Geriatr Soc 1985;33:671-80.

27. Fine MJ, Orloff JJ, Arisumi D, et al. Prognosis of patients hospitalized with community-acquired pneumonia. Am J Med $1990 ; 88: 1 \mathrm{~N}-8 \mathrm{~N}$.
28. Jin Y, Marrie TJ, Carriere KC, et al. Variation in management of community-acquired pneumonia requiring admission to Alberta hospitals. Epidemiol Infect 2002;129:1-11.

29. Powell J, Dugdale AE. Obstetric outcome in an aboriginal community: A comparison with the surrounding rural area. Aust J Rural Health 1999; 7:13-7.

30. Kvigne VL, Bull LB, Welty TK, Leonardson GR, Lacina L. Relationship of prenatal alcohol use with maternal and prenatal factors in American Indian women. Soc Biol 1998;45:214-22.

31. Westphal LL. Prenatal alcohol use among urban American Indian/Alaska native women. Am Indian Alsk Native Ment Health Res 2000;9:38-48.

32. Rodrigues S, Robinson EJ, Ghezzo H, Gray-Donald K. Interaction of body weight and ethnicity on risk of gestational diabetes mellitus. Am J Clin Nutr 1999;70:1083-9.

33. Thomson M. Heavy birthweight in Native Indians of British Columbia. Can J Public Health 1990:81:443-6.

34. Young TK, Kaufert JM, McKenzie JK, Hawkins A, O’Neil J. Excessive burden of end-stage renal disease among Canadian Indians: A national survey. Am J Public Health 1989;79:756-8.

35. Parker JD, Schoendorf KC, Kiely JL. Associations between measures of socioeconomic status and low birth weight, small for gestational age, and premature delivery in the United States. Ann Epidemiol 1994:4:271-8

36. Profile of Canada's Aboriginal Population, 1991 Census. Ottawa: Statistics Canada 1995:178. Cat. 94-325.

37. Statistics Canada. Aboriginal identity. <www.statcan.ca/english/ census2001/dict/pop001.htm> (Version current at June 22, 2004).

38. Ewig S, Ruiz M, Mensa J, et al. Severe community-acquired pneumonia. Assessment of severity criteria. Am J Respir Crit Care Med 1998;158:1102-8.

39. Marrie TJ, Lau CY, Wheeler SL, Wong CJ, Vandervoort MK, Feagan BG. A controlled trial of a critical pathway for treatment of community-acquired pneumonia. JAMA 2000;283:749-55.

40. Nichol KL, Margolis KL, Wuorenma J, Von Sternberg T. The efficacy and cost effectiveness of vaccination against influenza among elderly persons living in the community. N Engl J Med 1994;31:778-84.

41. Dominguez J, Gali N, Blanco S, et al. Detection of Streptococcus pneumoniae antigen by a rapid immunochromatographic assay in urine samples. Chest 2001;119:243-9. 


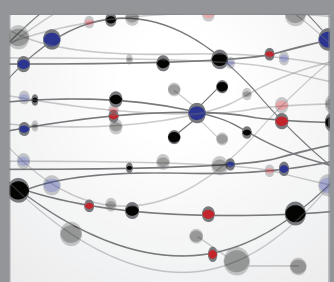

The Scientific World Journal
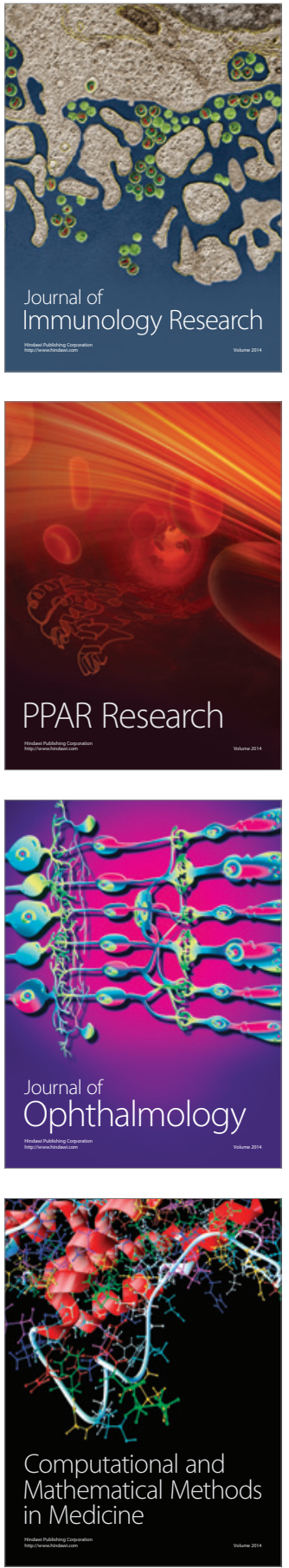

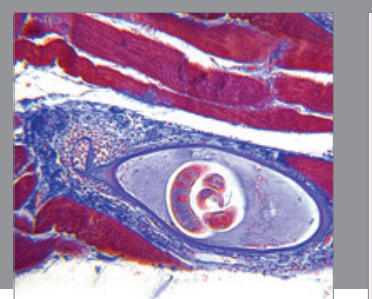

Gastroenterology Research and Practice

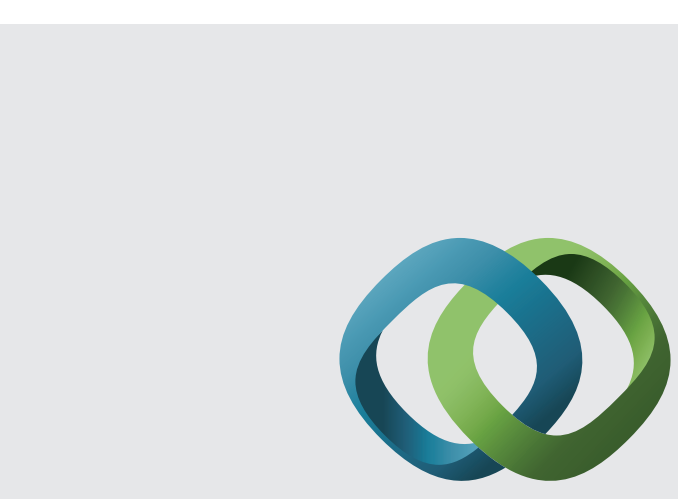

\section{Hindawi}

Submit your manuscripts at

http://www.hindawi.com
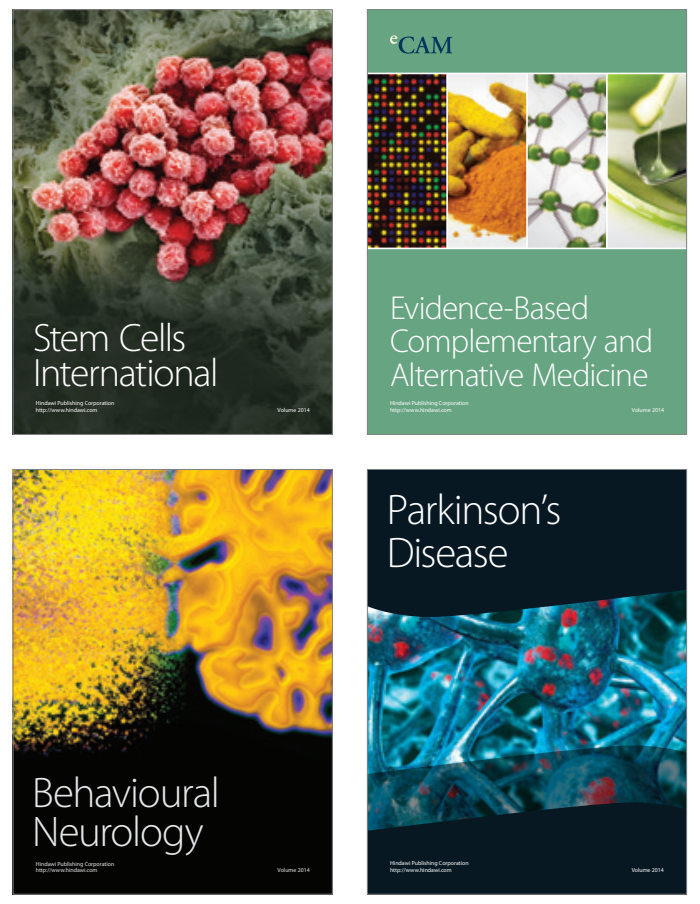
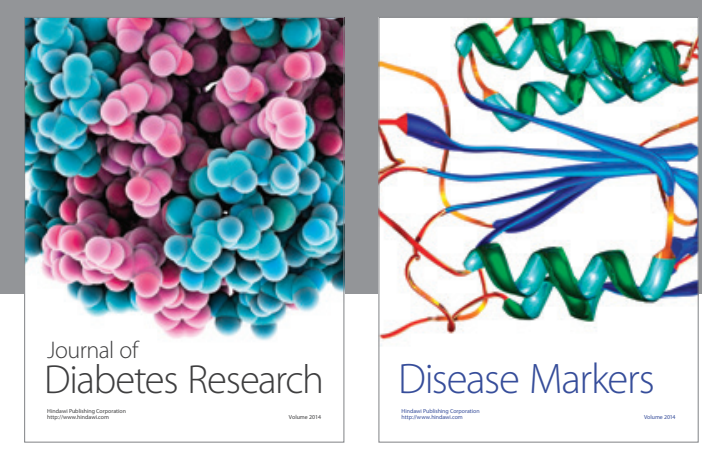

Disease Markers
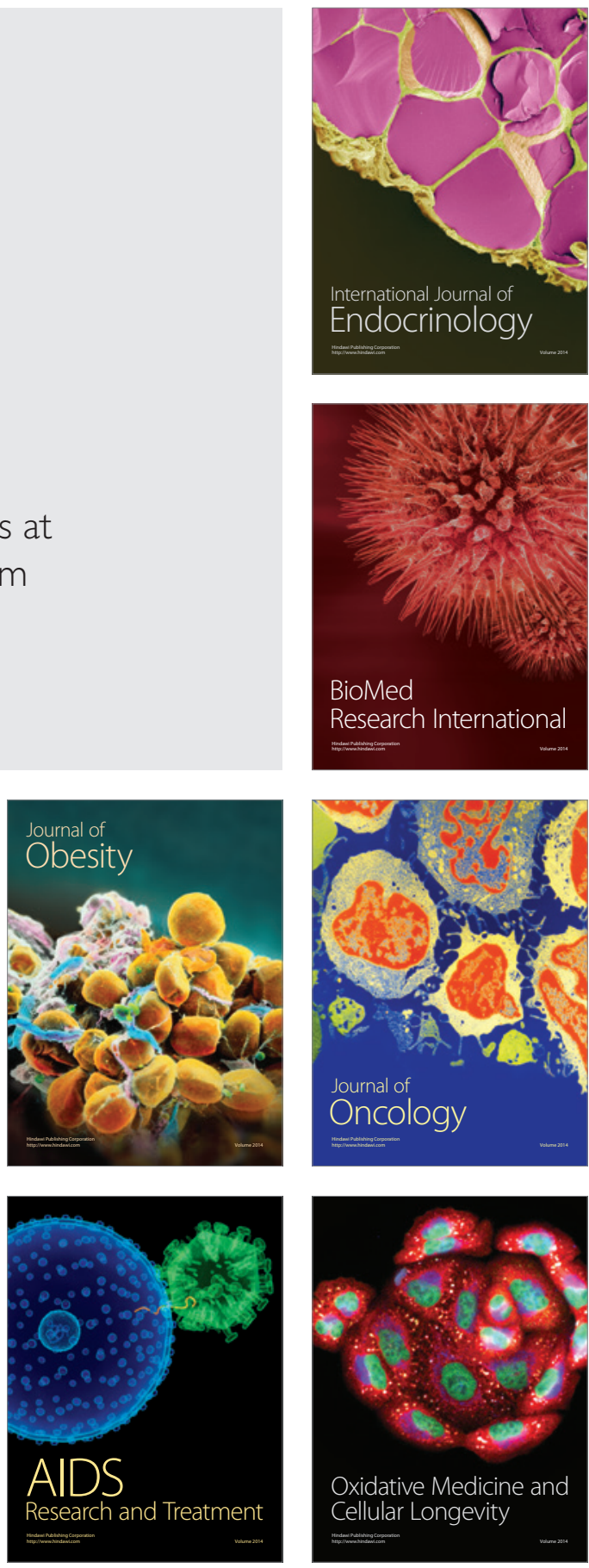